症例

腎癌術後 4 年目に肺転移，11年目に膵転移をきたした 1 例

東邦大学外科学講座 (大森) 一般 - 消化器外科, 同 第 1 病理"

$\begin{array}{lllllll}\text { 土屋 } & \text { 腾 } & \text { 金 子 弘 真 } \text { 大 塚 由一郎 } \\ \text { 田 } & \text { 村 } & \text { 晃 } & \text { 前 田 徹 也 } \text { 渋 谷 和 俊* }\end{array}$

症例は67歳，女性. 11 年前に腎癌で右堅摘出術を受け 7 年前に両側肺転移を認め切除 されている.経過中に腹部エコーで膵体部に低エコー腫瘤を認め, 画像診断上, hypervascular な特幑から転移性膵腫瘍の可能性が高いと診断された。手術は膵体尾部・脾合併切 除を施行し，病理組織学的所見から淡明細胞型と診断し，11年前の腎癌と肺転移の組織 像に一致し堅㿋膵転移と診断した。その後肺転移再発を認めIL-2を投与した。膵切除後 25力月現在, 肺転移の增大と再発は認めない. 堅癌の既往のある患者に hypervascular な腫㿉を訊めた場合には，転移の可能性を考虑すべきである．腎癌術後から膵転移まで の期間は比较的長いのが特徴であることを念頭に置き長期にわたる経過観察が重要であ る. 他腀器転移を伴う脺転移例の中にでも長期生存例もあり, 積極的な転移巣の切除に より，長期予後が期待できると考えられた。

慗引用語：堅癌，脺転移，肺転移

はじめに

腎癌は血行性転移しやすく，肺，肝，骨への転移は 多いが，膰への転移は比較的稀である。われわれは腎 癌術後 4 年目に両側肺転移をきたし, 眠転移切除の後 7 年目に膵転移を認め切除しえた 1 例を経験したのて 報告する。

\section{症例}

患者：67歳，女性.

主訴：特になし.

既往歴：特記すべきことなし.

家族歴：特記すべきことなし．

現病歴：平成 5 年, 腎癌 (clear cell type, pT2 N0 M0, stage II) のため右腎摘出術を受け, 平成 9 年, 両側肺転移を認め切除された。後経過観察中に腹部 超音波検査にて膵体部に腫瘍を指摘され精查加療目的 入院となった。

血洨検査所見：血液，生化学検查にて異常を認めな かった，腫痬マーカー(CEA, CA19-9) およびホルモ ン検査 (インスリン, ガストリン, ダルカコンン) では

2006年 7 月20日受付 2006年 8 月28日採用 〈所属施設住所〉

₹143-8541 東京都大田区大森西 6-11-1
異常を認めなかった。

腹部超音波所見：脺体部に 2 つの腫瘍病変を認め

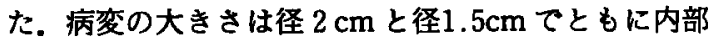
不均一な低エコー像を認め，カラードプラーにおいて

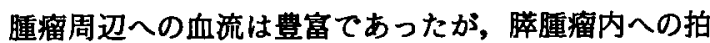
動性の血流は認めなかった（図 1 ）。

腹部 CT 検查所見：造影 CT では早期動脈相より濃 染する辺緣整で内部が均一な結節状腫㾇として認めら れ，晩期門脈相では膵実質と isodensity を呈していた (図 2 ).

腹部 MRI 検查所見：造影 MRI および T2強調像の いずれでも腫瘤は正常膵実質に比べは高信号として認 められた。

腹部血管造影検查 : 腹腔動脈撮影でも比較的早期か ら濃染される $2 つ 0$ hypervascularな腫瘍を脾動脈 に重なるように認められた（図３）。

以上の検㚗所見と堅癌の既往より堅癌の脺転移を疑い 手術を施行した。

手術所見：膵体部の腫瘍は境界明膫で限局しており 周囲組織への浸潤を認めなかった。腹水・腹膜播種・ 肝転移も認められず，膵体尾部・脾合併切除を施行し た.

切除榎本肉眼所見：膵体部に $20 \times 20 \mathrm{~mm}, 16 \times 24 \mathrm{~mm}$ 


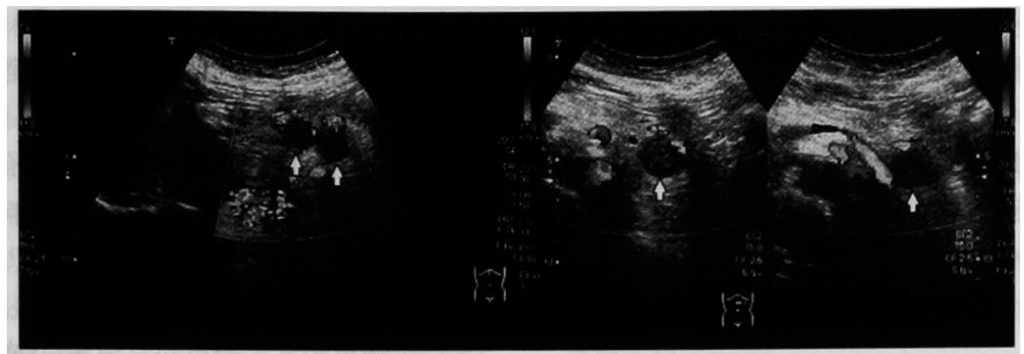

図 1 腹部超音波所見：膵体部に $\phi 2 \mathrm{~cm}$ と $\phi 1.5 \mathrm{~cm}$ てともに内部不均一な低工 コー像を認めた(矢印).カラードプラにおいて腫㿔周辺への血流は曹富であった が, 膵腫㩁内への血流は認めなかった。

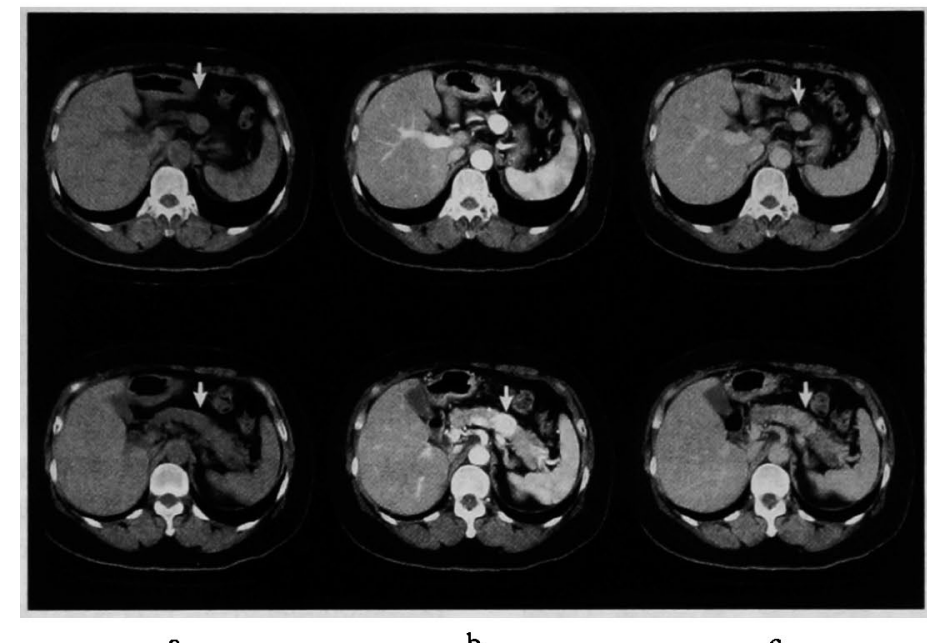

b

図 2 腹部 CT 検査所見（a：単純 CT b : 早期動脈相 c : 晚期門脈 相）：造影 CT では早期動脈相より濃染する辺縁整で内部が均一な結節 状腫溜として認められ，晚期門脈相では脺実質と isodensity を呈してい r.

大の黄色均一な円型腫瘍を認め，境界明瞭な円型腫痬 はいずれも被膜形成を伴い出血，壊死巣を認めなかつ た. 周囲への浸潤は認められなかった（図 4).

組織学所見：組緎学的には明調な大型細胞が索状胞 单を形成し，間質は類洞様の網細血管からなる．核の 大小および，核緑不整を伴う clear cell type の㹂癌の 転移と診断した。肺の組織像にも同様の clear cell type の細胞を認めた（図 5 ).

なお，今回術前より左肺に径 $1.0 \mathrm{~cm}$ の腫瘤陰影を認 め、肺転移再発と診断したが IL-2 (interleukin-2) 製 殽を週に 3 回投与を併用しながら経過観察した。脺転 移切除術後25力月経過した現在, 腹腔内再発および肺 陣慮陰影の増大は認めていない.
考察

腎㾔は多くは初診時すでに25〜30\%に多臓器転移を 認める予後不良な疾患である”．腎癌の転移は肺 $57 \%$ ， 骨 $49 \%$ ，肝 $8.7 \%$ あり脺への転移は $2.8 \%$ と少ない が，一方で転移性膵腫瘍は，剖検上10２0\%に確認さ れている、転移性膵腫瘍の原発巣は胃，肺，肝などが 多い3)4が大多数は病態の末期として出現するため，切 除の対象となるものはほとんどないとされる。

腎癌の原発巣治療後, 長期間再発や転移もなく経過 しても，何年も後になって転移巣が出現することがあ り，この long dormancy（長期潜伏）は最も留意する べき点であり゙，腎癌と診断されてから膵転移出現ま での平均期間は 10 年前後と非常に長いのが腎癌脺転移 
特徴の 1 つである6゙. 腎癌は原発巣としては少数て るが，坬立性あるいは膁限局の転移が多く切除率は い.

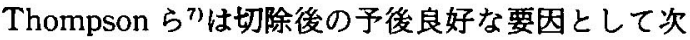
5つをあげている.

1) 原発巣切除から满転移出現までの期間が長い(10

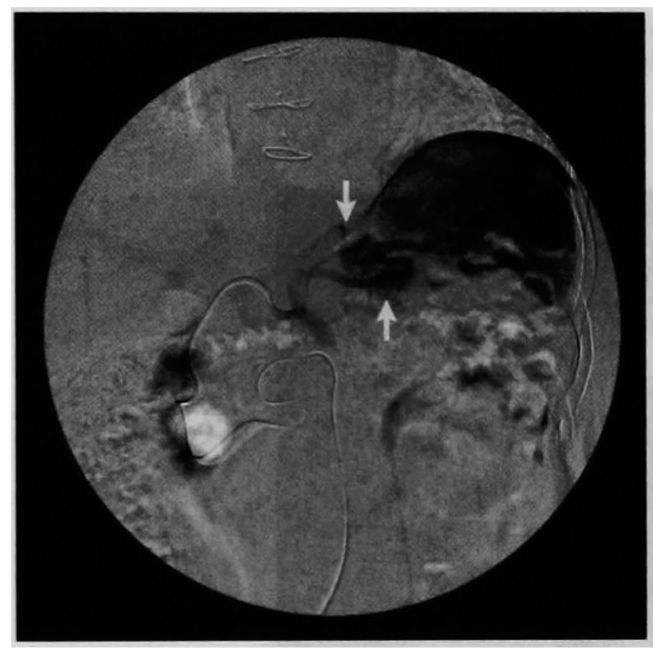

图 3 腹部血管造影検查：早期から涺染される2つ の hypervascular な腫境を腄動脈に重なるように 認めた。（矢印)
年以上)（2）膆転移が単発である（3）膆転移巣の自 然な退縮傾向 (4) 切除病巣の広範な壊死巣 (5) 腫 瘍の䌅徐な発育と自覚症状の欠如，である。

晚期再発とは堅摘出後10年以上経過後に認めた症例 と定義されており，その頻度は 10 年以上経過した症例 の $11 \% に$ 認めたと報告されている は 2 点考えられている97. 第 1 は長期間休眠状態にあ った再発巣がある時点から急激に増殖を始めた病態て あり, 第 2 は微小な再発巣の発育が緩徐である病態て

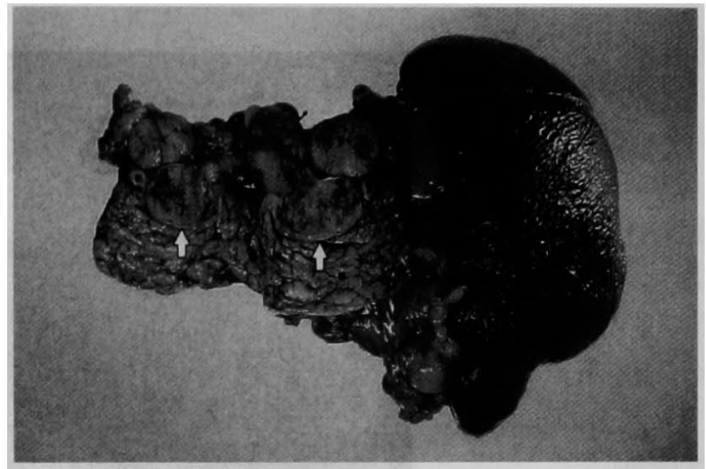

图 4 切除標本肉眼所見：膵体部に $20 \times 20 \mathrm{~mm}, 16 \times 24$ $\mathrm{mm}$ 大の黄色均一な円型腫晹を認めた。境界明眿な円 型の腫瘍はいずれも被膜形成を伴い出血, 壤死巣は認 めず，周囲への浸潤もなかった。

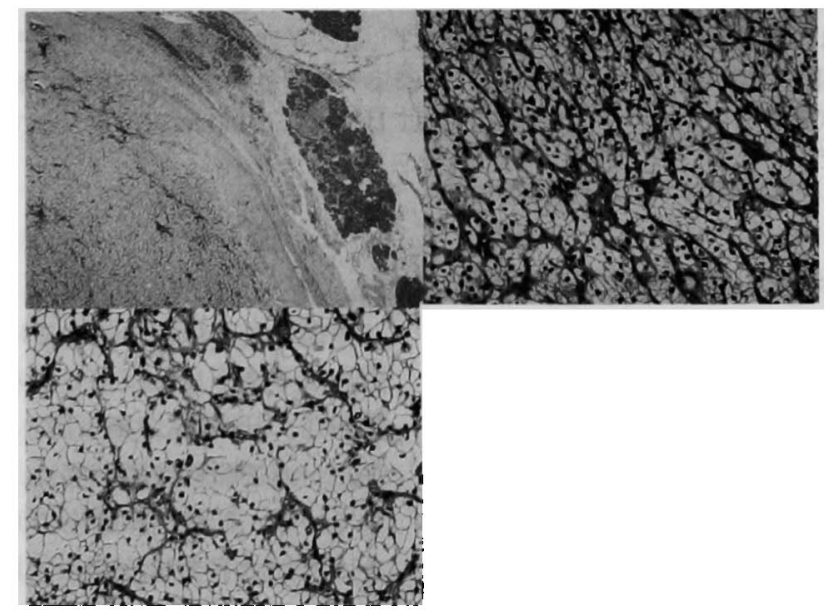

图 5 組織学所見：組織学的には明調な大型細胞が索状胞巣を形 成し，間質は類洞様の網細血管からなる，核の大小および、核縁 不整を伴う clear cell type の腎細胞癌の転移と診断した（a： $\mathrm{HE} \times 4, \mathrm{~b}: \mathrm{HE} \times 200)$ ．肺の組織像にも同様の clear cell type の細胞を認めていた（c：HE × 200）。 


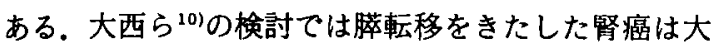
半が low stage で低悪性度のものであり，このような タイプの腫瘍に slow growing type が多く晚期再発を きたすものが多いことが推測されている，予後につい ては, 晚期再発例を集計した光井ら"1)の報告によると， 脺転移切除後 1 年以上の生存例が $34.3 \%$ ありり, 予後 は比較的良好であることが期待される。また膵転移切 除後の 5 年生存率は 68 〜 $75 \%$ との報告や平均生存期間 が19.8年 ${ }^{12)}$ との報告もあり, 通常型膵癌に比較しては るかに良好である。

督癌の膵転移の形態は単結節型，多結節型、びまん 型の 3 形態に大別される ${ }^{13)}$ が, 個々の腫煬は類円形で 比較的辺縁明瞙であり，びまん型といわれるものも多 数の結節が蜜に存在しており，腎癌の萃転移は基本的 に結節状に起こると考えられている(4). 堅癌膵転移の 画像上の特徵は腎癌の特徵である hypervascularity を反映し， CT 上強く enhance される腫瘤として描出 される.畽汮が均一に enhance されるものと内部に低 吸収域を含む場合があるが比較的小さな転移巣であっ ても内部に低吸収域を含むことが多い. hypovascular な原発性勝癌との篮別は容易であるが腎癌と同様に hypervascular な性格を有する膵内分泌腫瘍との鑑別 が困難である．特に非機能性腫湯の場合は無症状であ り鑑別は困難である。最近では Helical CTを用いた 3 phase study で腎癌の腆転移は early enhancement を呈し delayed phase では膵実質に density に近くな ることが報告されており 3 phase study の有用性が指 摘されている25)。しかし hypervascular な性格を有す る膵島細胞腫湯と腎癌膵転移との鑑別に対する有用性 は今後の検討が必要である.今回，われわれも 3 phase study にて娭討を行い，上記と同様の所見を得ること が出来たが，他腫場との鑑別は困難であり膵転移との 確定診断には至らなかった。したがって腎癌の既往と いうことが重要な鍵になると思われた。

督癌膵転移に対する治療方法は化学療法や放射線療 法の効果があまり期待出来ないことから外科的療法, インターフェロン療法あるいは両者の併用による治療

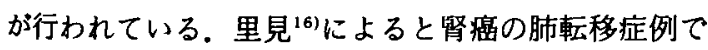
は肺転移手術例の 3 分の 1 が術後 1 年以内に死亡して いると報告している。しかし腎癌は比較的免疫原性が 高い腫場として知られ，他に有効な治療法を認めない 転移症例を中心に INF- $\alpha$ (interferon- $\alpha$ ) の投与が試 みられている(7).実際に腎癌肺転移症例を中心に INF

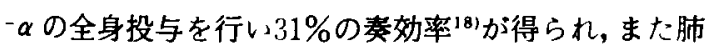

転移に対し IFN $-\alpha$ とIL-2の併用投与にて消失が得ら れたなどの報告がある ${ }^{19201}$. 自験例も stageの低い slow growing タイプであり腎摘から膵転移までは11 年かかっていた晚期再発型であった。膵に多発性に転 移しており，肺転移も認めていたことより，坬立性膵 転移症例よりは予後の悪いことも推測されたが, IL-2 療法を併用することで膵転移切除後25力月と長期生存 を得られている.

元井ら 21) は過去90例の腎癌膵転移症例の中から単変 量解析により塍外転移の有無のみが生存率に影響し, 再発巣手術時膵外に転移がある場合, 2 年生存率は $47.6 \%$. また阿久津ら ${ }^{22)}$ も膵転移のみの症例より膵以 外にも転移をきたしている症例の予後が不良と報告し ている.一方で自験例と同様に他臓器転移症例の中で 長期生存例 ${ }^{23)}$ も散見され, 根治手術が出来れば良好な 予後が期待できる可能性も示唆された，腎癌による萃 転移は線維性被膜を有することが多く，手技的には一 般に核出術が可能である.したがって腎癌の術後は長 期間にわたり経過観察が必要であり画像診断により卒 転移が疑われた症例に対しても積極的な切除により予 後が期待できるものと思われ24), 手術が可能な場合外 科的切除の適応になると考えられる。

結語

腎癌の既往がある患者に hypervascular な腫瘤を 認めた場合には，常に転移の可能性を考慮すべきであ ると考えられた。

堅癌術後から脺転移まての期間は比較的長いのが特 徵であう。このことを念頭に置き，腎癌は長期にわた る経過観察が重要であり, 皘極的な転移巣の切除によ り，長期予後が期待できると考えられた。

\section{まとめ}

堅癌術後 4 年目に両側肺転移をきたし，11年目に膵 転移を認め,切除しえた 1 例を経験したので報告した。

\section{文献}

1) Strijk SP: Pancreatic metastasis of renal cell carcinoma ; report of two cases. Gastrointest Radio 14: 123-126, 1989

2) Klugo RC, Detmers M. Stiles RE, et al : Aggressive versus conservative management of stage IV renal cell carcinoma. J Urol $118: 244-246$. 1977

3）小塚貞雄, 坪根幹夫, 滝 正：転移性荟癌の病 理学的研究。胆と脺 $11: 1531-1535,1980$

4) Abrams HL, Spiro R, Goldstein N : Metastasis 
in carcinoma. Analysis of 1000 autopsied cases. Cancer $3: 74-85,1950$

5) Ritchie AWS, Chisholm GD: The natural history of renal cell carcinoma. Seminars in Oncology $10: 390-399,1983$

6) Ghavamian R, Klein K A, Stephens D H, et al : Renal cell carcinoma metastatic to the pancreas:Clinical and radiological features. Mayo Clin Proc 75 : 581-585, 2000

7) Thompson L D, Heffess C S : Renal cell carcinoma to the pancreas in surgical pathology material. Cancer $89: 1076-1088,2000$

8) Mcnichols DW, Segura JW, Deweerd JH : Renal cell carcinoma : long-term survival and late recurrence. J Urol 126:17-23, 1981

9）石橋克夫, 福岡 洋, 土屋ふとし他：晚期再発し た腎細胞癌の 3 例．谂紀 $40 ： 229-232 ， 1994$

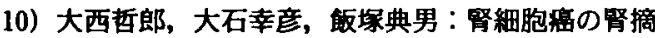
後粠に现立性転移を来した 7 症例の検討。日泾会 誌 $87 ： 1538-1542,1995$

11）光井富貫子，古川善也，趾星知博他：術後13年目 に膆轱移をきたし，切除し得た腎細胞癌の 1 例。 臨と研 $79: 1981-1985 ， 2002$

12) Law $C$ H, Wei A C, Hanna S S, et al : Pancreatic resection for metastatic renal cell carcinoma : Presentation, treatment, and outcome. Ann Surg Oncol $10:$ 922-926, 2003

13) Klein KA, Stephens DH, Welsh TJ : CT Characteristics of metastatic disease of the pancreas. Radiographics $18: 369-378,1998$

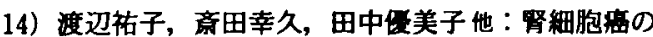
荟転移。臨放 $44: 1155-1161,1999$

15) $\mathrm{Ng}$ CS, Loyer EM, Iyer RB, et al : Metastasis to the pancreas from renal cell carcinoma ; findings on three-phase contrast enhanced helical CT. AJR Am J Roentgenol 172:1555-1559, 1999

16）里見佳昭：腎菭の治㟟の現況と今後の課題．日泌 会誌 $81 ： 1-13,1990$

17) Wirth MP:Immunotherapy for metastatic renal cell carcinoma. Urol Clin North Am 20 : 283-295, 1993

18) Quesada JR, Rios A, Swanson D: Antitumor activity of recombinant-derived interferon alpha in metastatic renal cell carcinoma. J Clin Oncol 3 : 1522-1528, 1985

19）高田俊彦，山田佳輝，宇野雅博他：集学的治療に より脳転移・肺転移が消失した腎癌の 1 例. 泌紀 $51: 381-384,2005$

20）稲土博右, 恩田 一, 小方康生他：Interleukin- I I （I L-2）にてCR を得た堅細胞癌肺転移の 1 例. 论外 $17: 1209-1213,2004$

21）元井冬彦, 福原賢治, 浅沼 拓他：切除17年後に 閉塞性黄㾝で発症した腎癌孤立性膵転移の 1 例一 本邦腎滛胖転移例の文献的考察一。胆と脺 25 ： $747-753,2004$

22）阿久津泰典，渡辺義二，鍋谷圭宏：堅摘後 4 年目 に脳轱移，8 年目に勝転移を来たした腎細胞癌の 1 治呤例。䏽瀻 $13 ： 415-419 ， 1998$

23）大西哲郎，大石幸彦，飯塚典男：堅細胞癌の腎摘 後朕に孤立性枟移を来した 7 症例の検討. 日泌会 誌 87：1538-1542, 1995

24）鈴木丈夫，島田莱稗子，佐藤克彦他：腎摘 9 年後

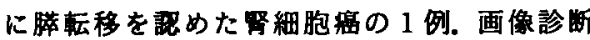
$20: 892-895,2000$ 


\title{
LUNG METASTASIS AND PANCREATIC METASTASIS AT 4 YEARS AND 11 YEARS AFTER NEPHRECTOMY FOR RENAL CELL CARCINOMA
}

\author{
Masaru TSUCHIYA, Hironori KANEKO, Yuichiro OTSUKA, \\ Akira TAMURA, Tetsuya MAEDA and Kazutoshi SHIBUYA* \\ Division of General and Gastroenterological Surgery, Department of Surgery (Omori), \\ First Department of Pathology*, Toho University School of Medicine
}

\begin{abstract}
We report a case of a 67-year-old woman who was admitted following the discovery of a mass lesion in the pancreas on abdominal ultrasonography. The patient had undergone right nephrectomy for renal cell carcinoma (RCC) 11 years previously, and bilateral partial lobectomy of lung for metastasis tumor from RCC 7 years ago. Abdominal echo showed hypervascular masses in the pancreatic body that were mostly probably metastatic lesions from RCC. She underwent a distal pancreatectomy. Histological examination of the specimen revealed metastatic tumor from RCC, which was diagnosed as clear cell carcinoma. She has been treated by IL-2 for recurrent lung lesion and has been living for 25 months after the operation with no evidence of metastasis. For a patient with hypervascular mass who has undergone surgery for RCC previously, we should consider that it might be metastasis from RCC. It takes a long time after surgery for RCC for pancreatic metastasis to occur therefore a long period of observation is neaded. It is suggested that aggressive surgery for metastatic pancreatic tumor from RCC would be a favorable option.
\end{abstract}

